\title{
A SHORT COMMUNICATION ON INHIBITORY AGENTS AGAINST SARS-COV2: VIRTUAL SCREENING AND DRUG REPURPOSING STUDIES
}

\begin{abstract}
Nearly 93 million individuals were infected and over two million died as a result of SARSCoV2. There was a pressing need to find a cure for this disease through a global, vigorous, and efficient research effort. Drug re-purposing was proven to be an effective method for discovering new uses for previously discovered medications in this venture. A total of 212 chemical entities were procured from PubChem and minimized using the PRODRG Server. From RCSB, RNAdependent polymerase enzyme (6M71), a receptor of SARS-CoV2 was procured. The 3-D structure of this receptor was minimized using ModRefiner and then the active site was predicted with Prank Web Server. Through GUSAR and SwissADME databases ligands that had proven successful in-screening were further investigated for pharmacokinetics properties. We found that just one medication establishes a low-energy H-bond with SARS-CoV2 viral protein out of the 212 tested. To combat SARS-CoV2, we report Edodolac that formed H-bonds with the pyridine group in PHE326 and PRO328. This drug's active core fragment interacted more strongly with the viral proteins than any other. Through ADMET research, these medicines show good pharmacokinetics features with the lowest acute toxicity. As an anti-inflammatory non-steroidal medication, etodolac has a binding energy of $5.6 \mathrm{kcal} / \mathrm{mol}$ and creates $\mathrm{H}$-bonds with the receptor's active residues.
\end{abstract}

Keywords: SARS-CoV2; Edodolac; NSAID; antiviral; virtual screening 


\section{Introduction}

Severe Acute Respiratory Syndrome (SARS-CoV2) is an acute virus that causes COVID-19 reported in Wuhan, China [1]. WHO classified it as a global pandemic because of its devastation and worldwide distribution [2]. This lethal disease is transmitted at a rapid rate in other parts of the world including the USA, which very soon became the global epicenter of COVID-19 [3]. SARS-CoV2 infects people of all ages, however, people already suffering from asthma, heart disease, diabetes, and geriatric people are the main target of this virus [4]. Research shows that SARS-CoV2 is found in $70 \%$ of alveolar macrophages that were located in the air sacs of the lungs. High expression of genes that were involved in inflammation was exhibited by the cells nursing the virus. This persistent lung inflammation could lead to some of the lifethreatening consequences of SARS-CoV2 infection [5]. It is possible to produce antiviral medications in a short time by repurposing existing drugs. Virtual screening of medications using docking simulations is typically the first step towards drug repurposing.

Extensive research efforts had been made by scientists to investigate the process of discovering potent therapeutic agents and specific target sites by using computational tools and Artificial Intelligence [9]. Because de novo drug designing is very lengthy, time-consuming, and expensive, therefore, scientists focused on another fundamental and alternative approach that helps in finding new indications for already discovered drugs, also known as drug repurposing or drug reprofiling [10]. Computational drug reprofiling is an economical and less time-consuming approach in this venture. This approach is much beneficial when the selected drugs were already approved by Food and Drug Administration (FDA) and had well-defined pharmacodynamics, pharmacokinetics, adverse effects, tolerability, and safety profile [11]. From virtual screening the scientists had found some new anti-viral drugs through Molecular Docking [12]. It is an important approach in the repurposing of the drug which was performed by analyzing the targeted protein catalytic site and finding the drug molecules that bind with it [13,14].

The drugs under clinical trials along with the mechanism of action for the treatment of SARSCoV2 are previously reported [6,7]. According to registered clinical trials, these pharmaceuticals are repurposed for the treatment of COVID-19. (https://clinicaltrials.gov, identifier NCT043505931, NCT04321174, NCT04342663, NCT04280705, NCT04244591, NCT04359329, NCT04348695, NCT04304313) [7]). A study reported 6,218 pharmaceuticals for 
COVID-19 using pharmacophore filtering both before and after the docking procedure. Seven of the 38 chemicals tested significantly inhibited SARS-CoV-2 in Vero and Calu-3 cells. (Fig. 1) [8].

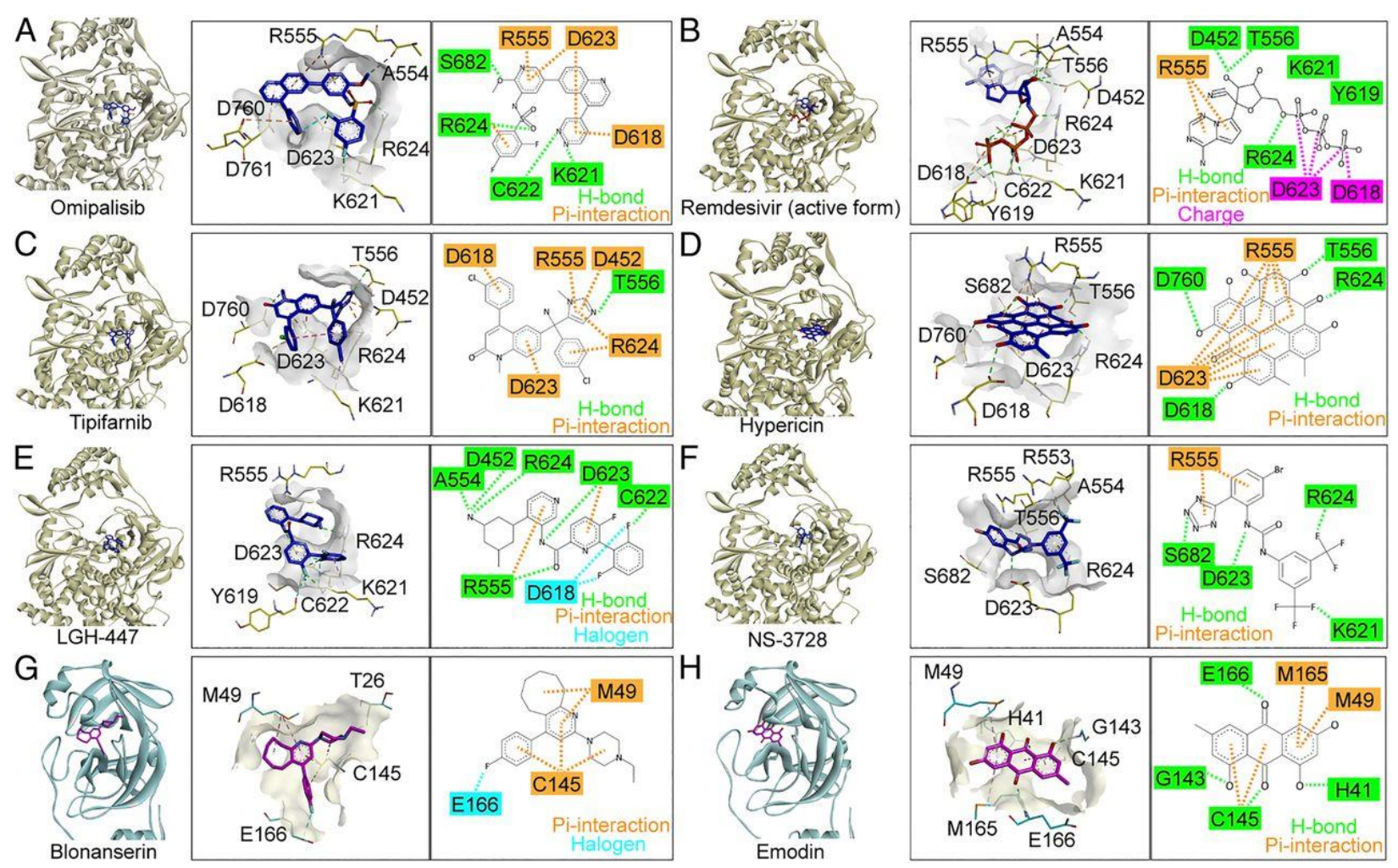

RNA-dependent polymerase enzyme ( $R d R p)$ and $\mathrm{M}^{\text {pro }}$ receptor sites for drug candidates. AutoDock Vina results of six drug candidates with RdRp-derived structure (PDB 6M71): (A) omipalisib, (B) remdesivir, (C) tipifarnib, (D) hypericin, (E) LGH-447, and (F) NS-3728. AutoDock Vina results of $\mathrm{M}^{\text {pro }}$ (PDB 6Y2F) with two drug candidates: (G) blonanserin and $(\mathrm{H})$ emodin. Creative commons [8].

Herein, we carefully selected 212 drugs other than those reported previously and conducted virtual screening analysis against $\mathrm{RdRp}$ receptor of SARS-CoV2.

\section{Materials and methods}

A total of 212 chemical entities approved by the FDA, were procured from PubChem and minimized using the PRODRG Server. From RCSB Protein Databank ID: 6M71 we downloaded RdRp, a receptor of SARS-CoV2, to test the interaction of these ligands. [15,16] The 3-D 
structure of this receptor was prepared and minimized using ModRefiner [17] and then the active site was predicted with Prank Web Server. PyRx 0.9 was used to screen these ligands for the determination of probable interaction against this receptor. Through GUSAR [18] and SwissADME [19] databases ligands that had proven successful in-screening were further investigated for pharmacokinetics properties. Molinspiration (https://www.molinspiration.com/cgi-bin/properties) was used for drug repurposing of already existing chemical entities utilized in this study.

\section{Results}

These 212 ligands were analyzed for drug-likeness and lead likeness criteria using SwissADME, to obtain efficacious compounds before screening analysis (Supplementary Table 1-2). From these, only 122 qualified these criteria and were further used for virtual screening against SARSCoV2 RNA Dependent RNA Polymerase (RdRP) enzyme. The results obtained from screening studies were further classified based on the type of chemical interaction of ligand and receptor, specifically, hydrogen interaction of ligands with the predicted active pocket of RdRP enzyme of SARS-CoV-2 were considered. Etodolac, an NSAIDs drug showed hydrogen bonding with 5.6 $\mathrm{kcal} / \mathrm{mol}$ of binding energy with the active residues of this receptor. This drug created hydrogen bonding with PHE326 and PRO328 with the pyridine group whereas the phenolic group formed pi-pi interaction with PHE396 respectively. 


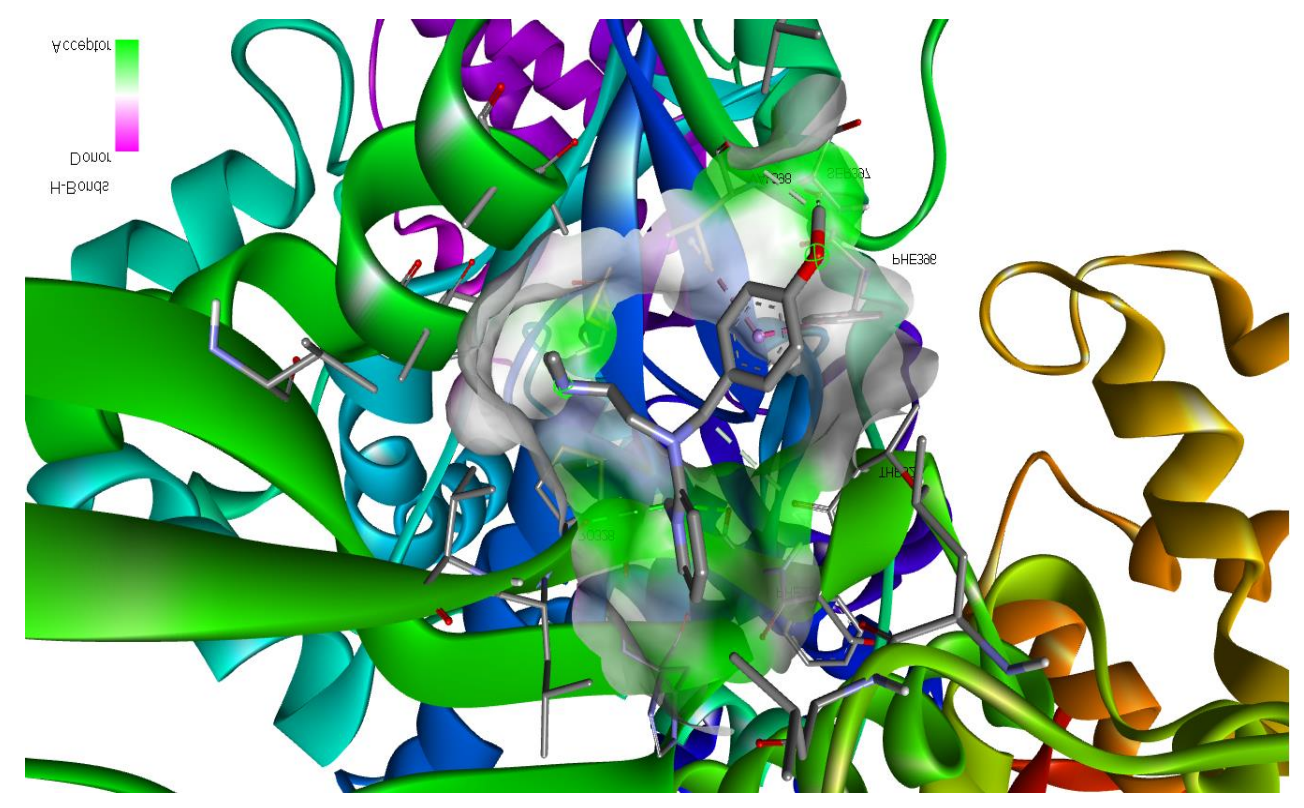

Fig 1. 3D Binding orientation of Etodolac with SARS-CoV2 RNA Dependent RNA Polymerase (RdRP) enzyme
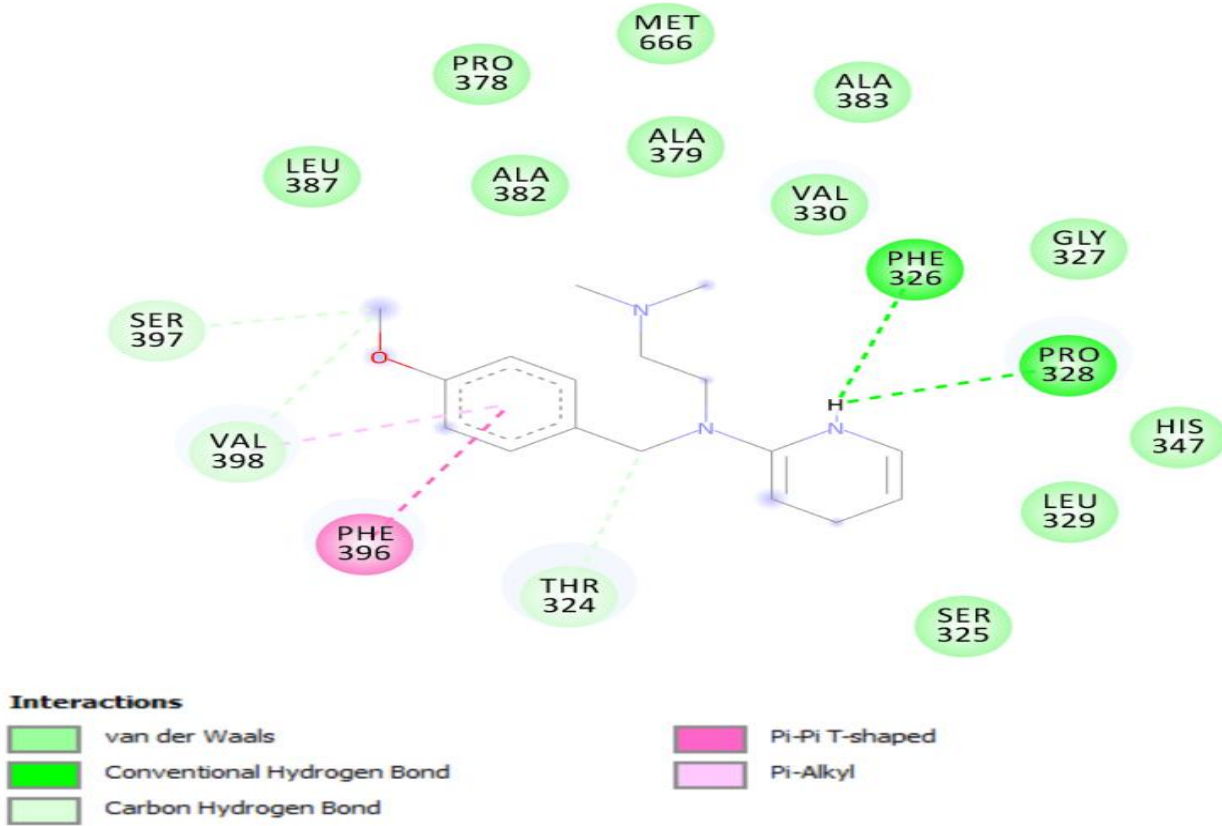

Pi-Pi T-shaped

Pi-Alkyl

Fig 2. Participation of Active Amino Acids Residues of SARS-CoV2 (RdRP) enzyme with Etodolac 


\section{Acute toxicity studies}

Acute toxicity study is based on examining the side effects that a drug may cause to test organism after single or multiple exposures through various routes including oral, intraperitoneal, intravenous, or subcutaneous route. GUSAR was used to check the acute toxicity of desirable compounds (Table 1). GUSAR analyzes the compounds based on their chemical structures and compares the acquired data with SYMYX MDL toxicity and the Organization of Economic Cooperation and Development (OECD) chemical classification database. The lethal dose of etodolac for the intraperitoneal route is $-0,439 \log _{10}(\mathrm{mmol} / \mathrm{kg})$, for the Intravenous route -0.690 , oral route 0.538 , and 0.014 for a subcutaneous route (Table 1 ). The obtained results from GUSAR chemically classified the screened drug in different classes through the OECD chemical classification system.

Table 1. GUSAR toxicity studies of Edodolac

\begin{tabular}{|c|c|c|c|c|c|c|c|c|}
\hline $\begin{array}{c}\text { DRUG } \\
\mathbf{S}\end{array}$ & $\begin{array}{c}\text { Rat IP LD50 } \\
\text { Log10(mmol } \\
\quad / \mathrm{kg})\end{array}$ & $\begin{array}{c}\text { Rat IV } \\
\text { LD50 } \\
\log 10(\mathrm{mmol} \\
/ \mathrm{kg})\end{array}$ & $\begin{array}{c}\text { Rat Oral } \\
\text { LD50 } \\
\log 10(\mathrm{mmol} \\
/ \mathrm{kg})\end{array}$ & $\begin{array}{c}\text { Rat SC } \\
\text { LD50 } \\
\log 10(\mathrm{mmol} \\
/ \mathrm{kg})\end{array}$ & $\begin{array}{c}\text { Rat IP } \\
\text { LD50 } \\
\text { Classificat } \\
\quad \text { ion }\end{array}$ & $\begin{array}{c}\text { Rat IV } \\
\text { LD50 } \\
\text { Classificat } \\
\quad \text { ion }\end{array}$ & $\begin{array}{c}\text { Rat Oral } \\
\text { LD50 } \\
\text { Classificat } \\
\quad \text { ion }\end{array}$ & $\begin{array}{c}\text { Rat SC } \\
\text { LD50 } \\
\text { Classificat } \\
\text { ion }\end{array}$ \\
\hline $\begin{array}{l}\text { Etodol } \\
\text { ac }\end{array}$ & 0,348 & $-0,690$ & 0,538 & 0,014 & Class 5 & Class 4 & Class 4 & Class 4 \\
\hline
\end{tabular}

\section{Pharmacokinetic properties}

Before animal and clinical trials, it is a prerequisite to finding out the pharmacokinetic properties of the compounds, their effects on organisms concerning absorption, metabolism, distribution, and excretion. From the Swiss ADME data, we obtained information regarding the drug-likeness and pharmacokinetics properties of screened compounds. The water solubility and gastrointestinal absorption values of these compounds were high. The compounds can cross BBB (blood-brain barrier) and satisfy the criteria of drug-likeness with zero violations. Along with that their physicochemical properties and lipophilicity were also checked. The data was then compiled and given in Table 2.

\section{Table 2. SwissADME study of Etodolac}




\begin{tabular}{|c|c|c|c|c|c|c|c|c|c|c|c|c|}
\hline DRUGS & \multicolumn{2}{|c|}{$\begin{array}{c}\text { Physicochemical } \\
\text { Properties }\end{array}$} & \multicolumn{2}{|c|}{ Lipophilicity } & \multicolumn{2}{|c|}{ Water Solubility } & \multicolumn{2}{|c|}{$\begin{array}{c}\text { Pharmacokin } \\
\text { etics }\end{array}$} & \multicolumn{2}{|c|}{ Druglikeness } & \multicolumn{2}{|c|}{$\begin{array}{l}\text { Medicinal } \\
\text { Chemistry }\end{array}$} \\
\hline \multirow{10}{*}{ Etodolac } & Formula & $\begin{array}{l}\mathrm{C} 17 \mathrm{H} \\
21 \mathrm{NO} \\
3\end{array}$ & $\begin{array}{l}\log P_{\mathrm{o} / \mathrm{w}} \\
(\mathrm{iLOGP} \\
)\end{array}$ & $\begin{array}{l}2 . \\
23\end{array}$ & $\begin{array}{l}\text { Log } S \\
(\mathrm{ESOL} \\
)\end{array}$ & -3.45 & $\begin{array}{l}\text { GI } \\
\text { absorpti } \\
\text { on }\end{array}$ & $\begin{array}{l}\mathrm{Hi} \\
\mathrm{gh}\end{array}$ & Lipinski & $\begin{array}{l}\text { Yes; } 0 \\
\text { violati } \\
\text { on }\end{array}$ & PAINS & 0 alert \\
\hline & $\begin{array}{l}\text { Molecular } \\
\text { weight }\end{array}$ & $\begin{array}{l}287.35 \\
\mathrm{~g} / \mathrm{mol}\end{array}$ & $\begin{array}{l}\log P_{\mathrm{o} / \mathrm{w}} \\
(\mathrm{XLOG} \\
\mathrm{P} 3)\end{array}$ & $\begin{array}{l}2 . \\
81\end{array}$ & $\begin{array}{l}\text { Solubil } \\
\text { ity }\end{array}$ & $\begin{array}{l}1.03 \mathrm{e}-01 \\
\mathrm{mg} / \mathrm{ml} ; \\
3.59 \mathrm{e}-04 \\
\mathrm{~mol} / \mathrm{l}\end{array}$ & $\begin{array}{l}\text { BBB } \\
\text { permea } \\
\text { nt }\end{array}$ & $\begin{array}{l}\mathrm{Ye} \\
\mathrm{s}\end{array}$ & Ghose & Yes & Brenk & 0 alert \\
\hline & $\begin{array}{l}\text { Num. heavy } \\
\text { atoms }\end{array}$ & 21 & $\begin{array}{l}\log P_{\mathrm{o} / \mathrm{w}} \\
(\mathrm{WLO} \\
\mathrm{GP})\end{array}$ & $\begin{array}{l}3 . \\
27\end{array}$ & Class & Soluble & $\begin{array}{l}\text { P-gp } \\
\text { substrat } \\
\text { e }\end{array}$ & $\begin{array}{l}\text { Ye } \\
\mathrm{s}\end{array}$ & Veber & Yes & $\begin{array}{l}\text { Leadliken } \\
\text { ess }\end{array}$ & Yes \\
\hline & $\begin{array}{l}\text { Num. from. } \\
\text { heavy atoms }\end{array}$ & 9 & $\begin{array}{l}\log P_{\mathrm{o} / \mathrm{w}} \\
(\mathrm{MLOG} \\
\mathrm{P})\end{array}$ & $\begin{array}{l}2 . \\
12\end{array}$ & $\begin{array}{l}\log S \\
\text { (Ali) }\end{array}$ & -3.78 & $\begin{array}{l}\text { CYP1A } \\
2 \\
\text { inhibito } \\
r\end{array}$ & $\begin{array}{l}\text { Ye } \\
\mathrm{s}\end{array}$ & Egan & Yes & $\begin{array}{l}\text { Synthetic } \\
\text { accessibili } \\
\text { ty }\end{array}$ & 3.47 \\
\hline & $\begin{array}{l}\text { Fraction } \\
\text { Csp3 }\end{array}$ & 0.47 & $\begin{array}{l}\log P_{\mathrm{o} / \mathrm{w}} \\
(\mathrm{SILIC} \\
\text { OS-IT) }\end{array}$ & $\begin{array}{l}4 . \\
31\end{array}$ & $\begin{array}{l}\text { Solubil } \\
\text { ity }\end{array}$ & $\begin{array}{l}4.81 \mathrm{e}-02 \\
\mathrm{mg} / \mathrm{ml} ; \\
1.68 \mathrm{e}-04 \\
\mathrm{~mol} / \mathrm{l}\end{array}$ & $\begin{array}{l}\text { CYP2C } \\
19 \\
\text { inhibito } \\
r\end{array}$ & $\begin{array}{l}\mathrm{Ye} \\
\mathrm{s}\end{array}$ & Muegge & Yes & & \\
\hline & $\begin{array}{l}\text { Num. } \\
\text { rotatable } \\
\text { bonds }\end{array}$ & 4 & $\begin{array}{l}\text { Consens } \\
\text { us } \\
\log P_{\mathrm{o} / \mathrm{w}}\end{array}$ & $\begin{array}{l}2 . \\
95\end{array}$ & Class & Soluble & $\begin{array}{l}\text { CYP2C } \\
9 \\
\text { inhibito }\end{array}$ & $\begin{array}{l}\mathrm{N} \\
\mathrm{o}\end{array}$ & $\begin{array}{l}\text { Bioavail } \\
\text { ability } \\
\text { Score }\end{array}$ & 0.85 & & \\
\hline & $\begin{array}{l}\text { Num. H- } \\
\text { bond } \\
\text { acceptors }\end{array}$ & 3 & & & $\begin{array}{l}\log S \\
\text { (SILIC } \\
\text { OS- } \\
\text { IT) }\end{array}$ & -5.20 & $\begin{array}{l}\text { CYP2D } \\
6 \\
\text { inhibito } \\
r\end{array}$ & $\begin{array}{l}\mathrm{Ye} \\
\mathrm{s}\end{array}$ & & & & \\
\hline & $\begin{array}{l}\text { Num. H- } \\
\text { bond donors }\end{array}$ & 2 & & & $\begin{array}{l}\text { Solubil } \\
\text { ity }\end{array}$ & $\begin{array}{l}1.81 \mathrm{e}-03 \\
\mathrm{mg} / \mathrm{ml} ; \\
6.31 \mathrm{e}-06 \\
\mathrm{~mol} / \mathrm{l}\end{array}$ & $\begin{array}{l}\text { CYP3A } \\
4 \\
\text { inhibito } \\
r\end{array}$ & $\begin{array}{l}\mathrm{N} \\
\mathrm{o}\end{array}$ & & & & \\
\hline & $\begin{array}{l}\text { Molar } \\
\text { Refractivity }\end{array}$ & 82.66 & & & Class & $\begin{array}{l}\text { Moderately } \\
\text { soluble }\end{array}$ & $\begin{array}{l}\text { Log } K_{\mathrm{p}} \\
\text { (skin } \\
\text { permeat } \\
\text { ion) }\end{array}$ & $\begin{array}{l}- \\
6 . \\
06 \\
c\end{array}$ & & & & \\
\hline & TPSA & $\begin{array}{l}62.32 \\
\AA^{2}\end{array}$ & & & & & & & & & & \\
\hline
\end{tabular}




\section{Molinspiration results}

The total 212 drugs utilized in this study demonstrated that mostly were kinase inhibitor as well as Ion-channel modulators. Whereas the least were GPCR ligand and enzyme inhibitors. (Fig.) The brief results are provided in the suppl Table.

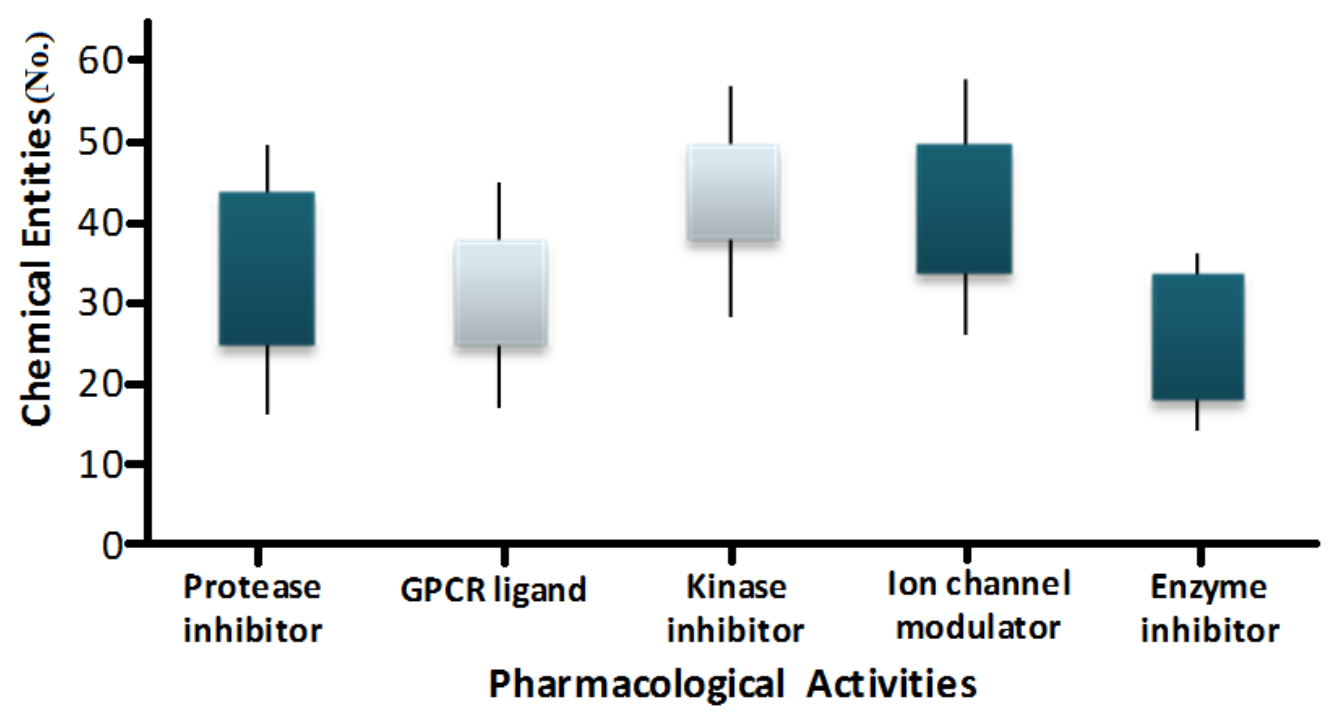

Fig. The pharmacological activities of chemical entities.

\section{Discussion}

Through drug repurposing studies, medications like remdesivir and interferons have demonstrated inhibitory effects against the SARS-CoV2 both in vitro and in clinical settings. Other drugs include tocilizumab, lopinavir, hydroxychloroquine, ritonavir, darunavir, arbidol, favipiravir, ribivarin, and chloroquine, which have shown inhibitory effects both in clinical and vitro settings. [20] We have previously reported that the use of anti-inflammatory [21] or immune modulatory agents [22], to treat COVID-19 is profound. Another study [23] also strongly supported the recommendation of using anti-inflammatory drugs to prevent deaths from COVID-19. They found that patients receiving the combination treatment had a median recovery time of seven days, versus eight days for the remdesivir-only group. They further stated that patients taking baricitinib and remdesivir had a 30\% greater improvement in clinical status at day 15 compared to the control arm [24]. 
According to J. Jesus Naveja and his co-workers, the use of curcumin along with invermectin had many favorable effects against apoptosis, inflammation, pulmonary edema suppression, replication of RNA, and pathways associated with fibrosis in SARS-CoV2 infection. Curcumin works as an anti-inflammatory agent by inhibiting cytokines storm, regulate inflammatory factors like COX-2 and interleukins that activate inflammatory responses [25]. Another group of researchers concluded that the risk of hospital administration of coronavirus patients with rheumatic chronic inflammatory disease was significantly reduced by using NSAIDs [26].

Within the viral protein, both structural proteins and non-structural proteins of the virus lies. For example, spike glycoproteins were the structural proteins that permit the viral compounds to attach themselves to the host cell ACE-2 receptor, (NSP-15, NSP-9) the non-structural proteins ease viral replication and along with this proteases inflect the manufacturing of diverse proteins via proteolytic cleavage [27,28]. In this study, our main objective was to achieve novel drug aspirants that comprise of three main characters one should retain their competent pharmacokinetic properties with the least toxicity, and to assure safety all along administration and must possess remarkable competency to interact with the targeted site of these viral proteins.

MOD refiner \& PRODRG servers were used for the preparation of both proteins and ligands to remove any worse contacts that may include structural abnormality and undesirable potential energy that results in pseudo interaction. To drain out most feasible drug candidates developing H-bonds except for van der Waals interaction, with viral protein receptors active site residues and to execute basic screening of these ligands the subtle molecules were recycled and meanwhile combined to raccoon [22]. The compound that established H-bonds with these fervid proteins was checked and further inspected for evaluating the interaction stability of the RMSD ligand via ligand RMSD [29]. In between 0.9-1.5 A was the estimated figure of RMSD of these compounds which were regarded as satisfactory and balanced.

By GUSAR software [18] and SwissADME [19], the acute toxicity and pharmacokinetic attributes of these compounds were determined. To evoke the toxic response these compounds require a high dose because the toxicity figure of these compounds was comparatively depressive. The Class 4 chemicals that contained the bulk of compounds had characteristic benign pernicious effects (diarrhea and piloerection), whereas Class 5 chemicals compound 
possess few toxic effects [22]. Thus, the dosage of these compounds should be measured as means to escapade their whole advantages and avoid negative effects.

The main indication of this coronavirus disease was the onset of a cytokine storm that was prevented by these medicinal compounds moreover these compounds revitalize immunological responses. By the combination of these medicinal compounds with basic anti-viral medicines, collegially intensifying the inhibitory action, lowers the toxic effects [30] boosts tissue repair and improves the sufferer's symptoms [31]. Assimilating these compounds with already approved drugs may establish a fair immunological response against this infection. Along with this, these compounds are also responsible for boosting up phagocytosis functions, and the proliferation of macrophages and neutrophils was also adjusted. By endorsing T-cells cytokine production they accelerate the activity of natural killer cells, adaptive immunity establishment, and stimulation of dendritic cells, which takes 4 to 7 days for activation. Thus through this intervention, the awful condition of infected individuals may be improved by boosting their immunity.

\section{Conclusion}

This study utilized virtual screening to find drugs with better pharmacokinetics, high binding affinity, and minimal toxicity. As a result of successful filtration, Etodolac was a viable therapeutic option for SARS CoV2. We did find that these chemical entities also have other pharmacological activities that are considered off-label. The toxicity studies demonstrated that Edodolac is a safe and viable therapeutic option. Our findings can therefore be used by doctors and other medical researchers in pursuit of promising anti-SARS-CoV2 agents. These drugs should be tested in clinical trials in both in-vivo and in-vitro settings. 


\section{References}

1. Jiang F, Deng L, Zhang L, Cai Y, Cheung CW, Xia Z. Review of the Clinical Characteristics of Coronavirus Disease 2019 (COVID-19). J Gen Intern Med. 2020;35: 1545-1549. doi:10.1007/s11606-020-05762-w

2. Dashraath P, Wong JLJ, Lim MXK, Lim LM, Li S, Biswas A, et al. Coronavirus disease 2019 (COVID-19) pandemic and pregnancy. Am J Obstet Gynecol. 2020;222: 521-531. doi:https://doi.org/10.1016/j.ajog.2020.03.021

3. McCreary EK, Pogue JM. Coronavirus disease 2019 treatment: A review of early and emerging options. Open Forum Infectious Diseases. 2020. doi:10.1093/ofid/ofaa105

4. Hui DS, I Azhar E, Madani TA, Ntoumi F, Kock R, Dar O, et al. The continuing 2019nCoV epidemic threat of novel coronaviruses to global health \&\#x2014; The latest 2019 novel coronavirus outbreak in Wuhan, China. Int J Infect Dis. 2020;91: 264-266. doi:10.1016/j.ijid.2020.01.009

5. Gómez-Rial J, Rivero-Calle I, Salas A, Martinón-Torres F. Role of Monocytes/Macrophages in Covid-19 Pathogenesis: Implications for Therapy. Infect Drug Resist. 2020;13: 2485-2493. doi:10.2147/IDR.S258639

6. Giollo A, Adami G, Gatti D, Idolazzi L, Rossini M. Coronavirus disease 19 (Covid-19) and non-steroidal anti-inflammatory drugs (NSAID). Ann Rheum Dis. 2021;80: e12--e12. doi:10.1136/annrheumdis-2020-217598

7. Sultana J, Crisafulli S, Gabbay F, Lynn E, Shakir S, Trifirò G. Challenges for Drug Repurposing in the COVID-19 Pandemic Era . Frontiers in Pharmacology . 2020. p. 1657. Available: https://www.frontiersin.org/article/10.3389/fphar.2020.588654

8. Jang WD, Jeon S, Kim S, Lee SY. Drugs repurposed for COVID-19 by virtual screening of 6,218 drugs and cell-based assay. Proc Natl Acad Sci. 2021;118: e2024302118. doi:10.1073/pnas.2024302118

9. Ojha PK, Kar S, Krishna JG, Roy K, Leszczynski J. Therapeutics for COVID-19: from computation to practices - where we are, where we are heading to. Molecular Diversity. Springer International Publishing; 2020. doi:10.1007/s11030-020-10134-x

10. Cusinato J, Cau Y, Calvani AM, Mori M. Repurposing drugs for the management of COVID-19. Expert Opin Ther Pat. 2020; 1-13. doi:10.1080/13543776.2021.1861248

11. Mishra D, Mishra A, Chaturvedi VK, Singh MP. An overview of COVID-19 with an emphasis on computational approach for its preventive intervention. 3 Biotech. 2020;10: 435. doi:10.1007/s13205-020-02425-9

12. Marinho EM, Batista de Andrade Neto J, Silva J, Rocha da Silva C, Cavalcanti BC, Marinho ES, et al. Virtual screening based on molecular docking of possible inhibitors of Covid-19 main protease. Microb Pathog. 2020;148: 104365. 
doi:https://doi.org/10.1016/j.micpath.2020.104365

13. Zhou Y, Hou Y, Shen J, Huang Y, Martin W, Cheng F. Network-based drug repurposing for novel coronavirus 2019-nCoV/SARS-CoV-2. Cell Discov. 2020;6: 14. doi:10.1038/s41421-020-0153-3

14. Singh P, Mishra N, Singh N, Nisha R, Pal RR, Singh S, et al. Credible Protein Targets and Curative Strategies for COVID-19: a Review. SN Compr Clin Med. 2020;2: 2067-2076. doi:10.1007/s42399-020-00526-3

15. Kim S, Thiessen PA, Bolton EE, Chen J, Fu G, Gindulyte A, et al. PubChem substance and compound databases. Nucleic Acids Res. 2015;44: D1202-D1213.

16. Wrapp D, Wang N, Corbett KS, Goldsmith JA, Hsieh C-L, Abiona O, et al. Cryo-EM structure of the 2019-nCoV spike in the prefusion conformation. Science (80- ). 2020;367: 1260 LP - 1263. doi:10.1126/science.abb2507

17. $\mathrm{Xu} \mathrm{D}$, Zhang Y. Improving the Physical Realism and Structural Accuracy of Protein Models by a Two-Step Atomic-Level Energy Minimization. Biophys J. 2011;101: 25252534. doi:https://doi.org/10.1016/j.bpj.2011.10.024

18. Mothay D, Ramesh K V. Binding site analysis of potential protease inhibitors of COVID19 using AutoDock. VirusDisease. 2020;31: 194-199. doi:10.1007/s13337-020-00585-z

19. Tian S, Hu N, Lou J, Chen K, Kang X, Xiang Z, et al. Characteristics of COVID-19 infection in Beijing. $\mathrm{J}$ Infect. 2020;80: 401-406. doi:https://doi.org/10.1016/j.jinf.2020.02.018

20. Singh TU, Parida S, Lingaraju MC, Kesavan M, Kumar D, Singh RK. Drug repurposing approach to fight COVID-19. Pharmacol Reports. 2020;72: 1479-1508. doi:10.1007/s43440-020-00155-6

21. Shah FH, Lim KH, Kim SJ. Do fever-relieving medicines have anti-COVID activity: an in silico insight. Future Virol. 2021;16: 293-300. doi:10.2217/fvl-2020-0398

22. Salman S, Shah FH, Idrees J, Idrees F, Velagala S, Ali J, et al. Virtual screening of immunomodulatory medicinal compounds as promising anti-SARS-COV-2 inhibitors. Future Virol. 2020. doi:10.2217/fvl-2020-0079

23. Grant RA, Morales-Nebreda L, Markov NS, Swaminathan S, Querrey M, Guzman ER, et al. Circuits between infected macrophages and $\mathrm{T}$ cells in SARS-CoV-2 pneumonia. Nature. 2021. doi:10.1038/s41586-020-03148-w

24. Titanji BK, Farley MM, Mehta A, Connor-Schuler R, Moanna A, Cribbs SK, et al. Use of baricitinib in patients with moderate and severe COVID-19. Clin Infect Dis. 2020.

25. Russell B, Moss C, Rigg A, Van Hemelrijck M. COVID-19 and treatment with NSAIDs and corticosteroids: should we be limiting their use in the clinical setting? 
Ecancermedicalscience. 2020;14: 1023. doi:10.3332/ecancer.2020.1023

26. Freites Nuñez DD, Leon L, Mucientes A, Rodriguez-Rodriguez L, Font Urgelles J, Madrid García A, et al. Risk factors for hospital admissions related to COVID-19 in patients with autoimmune inflammatory rheumatic diseases. Ann Rheum Dis. 2020;79: 1393 LP - 1399. doi:10.1136/annrheumdis-2020-217984

27. Kipshidze N, Iversen P, Porter TR, Kipshidze N, Siddiqui F, Dangas G, et al. Targeted, Site-Specific, Delivery Vehicles of Therapeutics for COVID-19 Patients. Brief Review. Clin Appl Thromb. 2020;26: 1076029620954911.

28. Hoffmann M, Kleine-Weber H, Schroeder S, Krüger N, Herrler T, Erichsen S, et al. SARS-CoV-2 Cell Entry Depends on ACE2 and TMPRSS2 and Is Blocked by a Clinically Proven Protease Inhibitor. Cell. 2020;181: 271-280.e8. doi:10.1016/j.cell.2020.02.052

29. Mittal L, Kumari A, Srivastava M, Singh M, Asthana S. Identification of potential molecules against COVID-19 main protease through structure-guided virtual screening approach. J Biomol Struct Dyn. 2020; 1-19. doi:10.1080/07391102.2020.1768151

30. Kandeel M, Al-Nazawi M. Virtual screening and repurposing of FDA approved drugs against COVID-19 main protease. Life Sci. 2020;251: 117627. doi:https://doi.org/10.1016/j.lfs.2020.117627

31. Jin Z, Du X, Xu Y, Deng Y, Liu M, Zhao Y, et al. Structure-based drug design, virtual screening and high-throughput screening rapidly identify antiviral leads targeting COVID19. bioRxiv. 2020; 2020.02.26.964882. doi:10.1101/2020.02.26.964882 